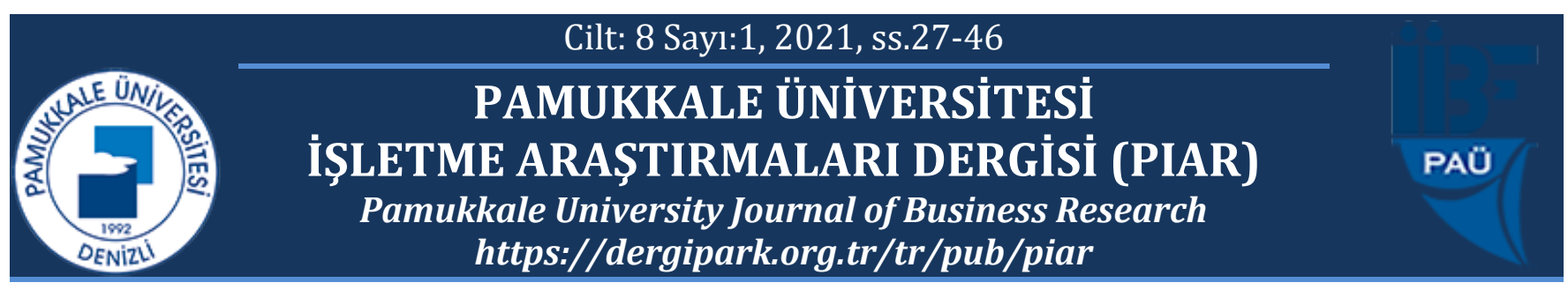

\title{
Psikolojik Sermayenin Örgütsel Bağlılık Üzerindeki Etkisinde İş-Yaşam Dengesinin Aracılık Rolü: Bir Araştırma*
}

\section{The Mediating Role of Work-Life Balance in the Effect of Psychological Capital on Organizational Commitment: A Study}

\section{Durmuş Bilge AKKUŞ1}

\section{Seyil NAJIMUDINOVA²}

\section{Hasan GÜL ${ }^{3 *}$}

\author{
1bilgekagan_669@hotmail.com, https://orcid.org/0000-0002-8751-608X \\ ${ }^{2}$ Kırgızistan-Türkiye Manas Üniversitesi, İ̈BF, İşletme Bölümü, seyil.najimudinova@manas.edu.kg, \\ https://orcid.org/0000-0003-3848-6635 \\ 3Ondokuz Mayıs Üniversitesi, İ̈BF, İşletme Bölümü, hasan.gul@omu.edu.tr, https://orcid.org/0000-0002-3720-5451 \\ *Yazışılan Yazar/Corresponding author
}

\section{Öz}

Bu çalışmanın amacı psikolojik sermayenin örgütsel bağgllık üzerindeki etkisinde iş-yaşam dengesinin aracılık rolünü üniversite çalışanları örnekleminde incelemektir. Literatürde söz konusu değişkenler arasındaki ilişkileri ele alan sınırlı sayıda çalışmanın ortaya konulduğu görülmektedir. Bu noktada, daha önce ilgili alanda yapılmış çalışmalara destek olması ve sonrasında yapılacak çalışmalara katkı să̆lanması amacıyla, üniversitede çalışmakta olan 411 akademik ve idari personel üzerinde anket uygulaması gerçekleştirilmiştir. Araştırmaya konu olan üç değişkenin her biri için kontrol değişkenleri aracılı̆̆ıyla farklılık analizleri gerçekleştirilmiş olup, çalışanların demografik özelliklerine göre birtakım farklılıklar olduğu bulgusuna ulaşılmıştır. Elde edilen bulgular doğrultusunda psikolojik sermayenin örgütsel bă̆gllık ve iş-yaşam dengesi üzerinde ve iş-yaşam dengesinin de örgütsel bağlllık üzerinde olumlu etkisinin olduğu ayrica psikolojik sermayenin örgütsel bağhllık üzerindeki etkisinde iş-yaşam dengesinin kısmi aracılık rolünün bulunduğu belirlenmiştir. Uygulanan bootstrap ve Sobel testi sonuçları da iş-yaşam dengesinin kısmi aracılık rolünün anlamlı olduğunu göstermiştir.

Anahtar kelimeler: Psikolojik Sermaye, Örgütsel Bă̆lılık, Işs-Yaşam Dengesi, Aracılık Etkisi, Üniversite

JEL kodlari: M12, M19

\begin{abstract}
Main objective of this research is to find out the mediating role of work-life balance in the relationship between psychological capital level and organizational commitment level of the employees. It is seen that a limited number of studies that deal with the relationships between these variables have been presented in the literature. At this point, a survey was conducted on 411 academic and administrative staff working at the university in order to support previous studies in the relevant field and to contribute to future studies. For each of the three variables that are the subject of the research, differences were analyzed by means of control variables, and it was determined that there were some differences according to the demographic characteristics of the employees. In line with the findings, it has been determined that psychological capital has a positive effect on organizational commitment and work-life balance and work-life balance on organizational commitment, and psychological capital has a partial mediating role in the effect of organizational commitment. The applied bootstrap and Sobel test results also showed that the partial mediating role of work-life balance is significant.
\end{abstract}

Keywords: Psychological Capital, Organizational Commitment, Work-Life Balance, Mediating Effect, University

JEL codes: M12, M19

\footnotetext{
*Bu makale Durmuş Bilge Akkuş'un Yrd. Doç. Dr. Seyil Najimudinova'nın danışmanlığında (Eş Danışman Prof. Dr. Hasan Gül) yürütülen “Psikolojik Sermayenin Örgütsel Bağlllık Üzerindeki Etkisinde İş-Yaşam Dengesinin Aracılık Rolü: KTMÜ Örneği” başlıklı doktora tezinden türetilmiştir.
} 


\section{GİRIŞ}

$\mathrm{Bu}$ araştırmanın temel amacı, üniversitelerde psikolojik sermayenin çalışanların örgütsel bağlılıkları üzerindeki etkilerini belirlemek, ayrıca çalışanların iş-yaşam dengelerinin bu iki faktör üzerindeki aracılık rolünü ortaya çıkarmaktır.

Literatürde son yıllarda yapılan çalışmalar, örgüt içi uyum ve birlikteliğin çalışanın verimliliğini, örgütsel vatandaşlık davranışını ve örgütsel bağlılığııı çeşitli açılardan inceleyip destekleyen sonuçları ortaya koymaktadır. Psikolojik sermaye ile örgütsel bağlılık arasındaki ilişkiyi inceleyen çeşitli araştırmalarda hem psikolojik sermayenin hem de örgütsel bağlılığın çeşitli alt boyutları arasında ilişki olduğu ortaya çıkarılmıştır (Luthans vd., 2007; Avey vd., 2011; Çetin, 2011). Fakat bu ilişki kapsamında literatüre bakıldığında “işyaşam dengesinin" psikolojik sermayenin örgütsel bağlılık üzerindeki etkisinde aracılık rolünü ortaya çıkarmaya yönelik bir araştırmaya rastlanmamıştır. Bu bağlamda söz konusu araştırmayla iş-yaşam dengesinin bu iki faktör arasındaki ilişkiye etkisinin ortaya çıarılmasının konuya farklı bir bakış açısı getirmesi ve literatüre bir model önerisinde bulunması beklenmektedir. Ayrıca bu ilişkilerin farklı ülkelerden akademik ve idari personele sahip bir üniversitede ilk defa incelenmesi daha sonra yapılacak olan çalışmalarda sektör, üniversite ve ülke karşılaştırmalarının yapılmasına imkân sağlaması açısından da literatüre katkı sağlayacağı umulmaktadır. Bu çalışma kapsamında, Bişkek şehrinde bulunan özel statülü devlet üniversitesi olan Kırgızistan-Türkiye Manas Üniversitesi'nde görev yapmakta olan 411 akademik ve idari personel üzerinde anket uygulaması yapılmış olup; elde edilen veriler "SPSS 23.0" ve "IBM SPSS Amos v.24" programları aracılığıyla analiz edilmiştir.

\section{KAVRAMSAL ÇERÇEVE}

\subsection{Psikolojik Sermaye}

Literatüre bakıldığında uzman psikologların, araştırmacıların ve akademisyenlerin olumsuz durumlar olan stres düzeyi, kaygı bozuklukları, tükenmişlik sendromu ve istenenden az performansa sahip olma gibi konular üzerine daha çok eğilmelerine karşın çalışanların mutlu olmalarını sağlayan iş tatmini ve örgütsel bağlılı̆̆ın artmasına yönelik faktörlere yeterince ilgi göstermemeleri pozitif psikoloji akımının geliştirilmesine yol açmıştır (Peterson vd., 2011: 443).

Psikolojik sermaye, bireyin, zorlu görevlerde başarılı olmasını ve gerekli çabayı göstermesini sağlamaya yönelik güveni yansıtmaktadır. Şimdiki zamanda ve gelecek hayatta başarıya ulaşmak gayesiyle pozitif (iyimserlik) hedefler yönünde hareket etmeyi ve yeni yollar bulmaya çalışarak (umut) başarıya ulaşmayı, aynı zamanda başarıya götüren yolda ilerlerken karşısına çıkan problemlere ve güçlüklere karşı dayanıklı olmayı (psikolojik dayanıklılık) kapsayan pozitif psikoloji kavramının geliştirilerek daha iyi duruma getirilmiş halidir (Avey vd., 2008: 4). Ayrıca psikolojik sermaye faktörlerinin bir araya getirilmesi sayesinde oluşan sinerjinin yüksek olması sonucu, çalışanın performansının ve yaptığı görevden aldığ tatminin belirlenmesinde, bu sinerjiyi oluşturan her bir faktörden daha fazla açılayıcı gücü bulunan çekirdek bir yapı olduğu ortaya çıkarılmıştır (Luthans vd., 2006: 388). 
Çalışma kapsamında psikolojik sermaye kavramı dört alt boyut açısından incelenmektedir. Bunlar; öz yeterlilik, umut, iyimserlik ve psikolojik dayanıklılıktır. "Öz Yeterlilik” kişinin çalışma hayatında belirlenen sonuçlara ulaşabilmek için gerek duyduğu kaynakları kullanabilme yeteneğine duyduğu inancı ifade etmektedir. "Umut" kişinin gerektiğinde yeni yollar belirleyerek hedefine ulaşmak için istekliliğini; "İyimserlik" çalışma alanında başarıya ulaşabilmeye dair olumlu beklentileri; "Dayanıklılık" ise çalışanın ne olursa olsun başarıya ulaşmak için karşısına çıkan zorluklarla başa çıkabilme yeteneğini işaret etmektedir.

\section{2. Örgütsel Bağlılık}

Örgütsel bağlllık, bireysel eylemleri örgütsel hedeflere yönlendiren içsel ve istikrarlı bir güçtür. Kavram çeşitli nedenlerden dolayı örgütsel araştırmacıların dikkatini çekmiştir. Yıllar boyunca, farklı araştırmacılar örgütsel bağlılığın maliyet, devamsızlık ve performans gibi çalışan davranışlarıyla ilişkisini; çalışanın yaş, cinsiyet, başarı ihtiyacı ve iş süresi gibi kişisel özelliklerini (Angle ve Perry, 1981; Steers, 1977), işle ilgili tutumsal, duygusal ve bilişsel kavramları, memnuniyet ve işe katılım sürecini (Hrebiniak ve Alutto, 1972; Porter, 1974); özerklik ve sorumluluk gibi iş özelliklerini (Koch ve Steers, 1978), iş çeşitliliği ve görev kimliğini (Steers, 1977) ve rol çatışması ve rol stresini (Morris ve Koch, 1979) incelemişlerdir.

İlk kez ele alındığg 1956 tarihinden bugüne kadar literatürde örgütsel bağlllıkla ilgili birçok farklı kavramın kullanıldığı bilinmektedir. Örneğin; Protestan iş ahlakı, mesleki bağlılık, çalışma arkadaşlarına bağlılık, işe tutkunluk ve işe sarılma gibi (Gül, 2003: 46).

Örgütsel bağlılık, çalışanın kimliğinin kuruluşun hedefleri ve değerleriyle örtüşmesi (Mowday vd., 1982) ve süpervizörün gücünün ölçüsüdür. Örgüte adanmış bireyler ekstra çaba göstermekte, örgütsel üyeliğin sürmesini istemekte (Morrow, 1993), örgüt varlıklarını korumakta ve örgüt hedeflerini ve değerlerini paylaşmaktadırlar (Meyer ve Allen, 1997). Bu tutkunluk, çalışanların iş tatmini, motivasyon ve performans dahil olmak üzere çeşitli arzu edilen iş sonuçlarıyla ilişkilidir (Mathieu ve Zajac, 1990). Ancak bağlılık davranışları bireylerden ve alt gruplardan örgütün tamamına aktarılmazsa, hedefleri örgütün hedefleri ile çelişen çalışanlar arasında işlevsiz davranışların ortaya çıkmasına yol açabilmektedir (Vandenberg ve Scarpello, 1994).

Örgütlerin amaç ve hedeflerine ulaşabilmek amacıyla çalışanlarının motivasyonunu yüksek tutması ve kendisine bağlaması olarak açıklanabilecek örgütsel bağlılık kavramı Allen ve Mayer tarafından üç alt boyutta incelenmiştir. Çalışmaya konu olan bu alt boyutlardan "Duygusal Bağlılık" çalışanları örgüte duygu bakımından yaklaştıran ve çalıştığı örgütün bir parçası olmaktan dolayı mutlu kılan duyguları ifade etmektedir. "Devamlılık Bağlılığı" çalışanın, örgütten ayrılmasının getireceği zorlukları göz önüne alarak, bireysel beklenti ve istekleri doğrultusunda örgüt üyeliğini devam ettirme davranışında bulunmasını açıklamakta; "Normatif Bağlılık" ise örgütün çalışan için daha önce yaptığı faaliyetlerin ve fedakârlıkların hatırına çalışanın kendisini örgüte borçlu hissetmesi gibi durumları açıklamaktadır.

Örgütsel bağlılık, çeşitli davranışsal ve tutumsal sonuçlara yol açmaktadır. Bağlılı̆̆ın daha yüksek motivasyon düzeyi ve örgütsel vatandaşlık davranışı ile pozitif ilişkili (Meyer ve Allen, 1997; Mowday, 1999) olduğu bulunmuştur. Buradan hareketle, ilgili literatür incelendiğinde psikolojik sermaye ile örgütsel bağlılık arasında anlamlı bir ilişki olduğu 
görülmektedir (Çoban 2013; Çelik, Turunç ve Bilgin, 2014; Özen Kutanis ve Oruç, 2014; Mercan vd., 2015; Yeşil, Yetiş ve Telli, 2016; Begenirbaş ve Turgut, 2016; Ocak, Güler ve Basım, 2016; Karacan, 2018; Uygungil ve İşcan, 2018; Ekin, 2018; Altan ve Özpehlivan, 2018).

\section{3. İş-Yaşam Dengesi}

İnsan yaşamının devamlılığına yaptığı katkı açısından iş, hayati bir öneme sahiptir. Hayatın birbirini tamamlayan, biri olmadan diğerinin eksik kaldığ1 düşünülen bir bütün olması sebebiyle iş ve yaşam dengesinin birbirinden ayrı düşünülmesi olanaksızdır (Yüksel, 2004: 48). Çünkü sahip olunan iş, kişinin içinde bulunduğu toplumda bir konuma sahip olmasında, günlük hayatın gerekliliklerini karşılamasında, hayattan alınan zevkin ve doyumun artmasında, ailesine sağladığı maddi ve manevi imkanların zenginleşmesinde belirleyici bir konuma sahip olmaktadır (Bruck vd., 2002: 3).

Kişinin iş alanı ise; yaşamında önemli bir alan kapsayan yalnızca bir kazanç elde etme yöntemi değil, aynı zamanda sosyal gereksinimleri de karşılayan bir konumdadır (Tuncer ve Yeşiltaş, 2013: 60). Dolayısıyla iş, çalışanlar açısından ekonomik olduğu kadar psikolojik ve sosyal anlamlar da içermektedir. Bireyin motivasyonundan sosyal statüsüne, ekonomik özgürlügünden evliliğinin kalitesine kadar geniş bir yelpaze içerisinde etkili ve belirleyici olmaktadır.

İş-yaşam dengesi, kişinin çalıştı̆̆ 1 iş ile işten sonraki sosyal hayatındaki roller arasında çatışmanın olmaması veya minimum düzeyde olması anlamına gelmektedir (Clark, 2000: 749). Başka bir deyişle, iş-yaşam dengesi çalışanın iş ve iş dişındaki sosyalleşme çabaları üzerinde kontrol sahibi olması şeklinde ifade edilmektedir (Barnett, 1999: 143). Diğer bir tanıma göre, bireyin kişisel ihtiyaçları ile iş ve aile hayatından gelen taleplerin uyumlu hale gelmesi durumudur (Pichler, 2009: 451).

Küreselleşme ile beraber toplumlarda ekonomik, sosyal ve kültürel değişimler meydana geldiği bilinmektedir. Toplumu oluşturan insanların bu değişimlerle beraber daha fazla ürün ve hizmeti talep etmesi sonucunda daha fazla çalışmayı kabul etmesi durumu da ortaya çıkmıştır. Daha fazla çalışmayı göze alırken aynı zamanda özel hayatları ile iş yaşamları arasında belli bir dengeyi sağlama zorunluluğu da belirginleşmiştir. Bu bağlamda iş-yaşam dengesi, çalışanların sorumluluklarını yerine getirirken aynı zamanda aile ilişkilerini de belirli bir düzeyde tutarak onlara gerekli ilgi ve davranışları gösterebilmesi olarak tanımlanabilmektedir (Sayın, 2017: 28).

Kişinin sadece işinden memnun olması yeterli görülmemektedir. İşinden memnun olsa da kişi özel hayatına yeterince vakit ayırabilirse, kendisini istediği alanlarda geliştirebilecek ve bunlardan aldığ deneyimler sayesinde işine de pozitif yönlü katkıda bulunabilecektir. İş dışı faaliyetlere vakit ayıramayan dolayısıyla kendini geliştiremeyen bireyin ise işe katkısı zamanla durağan vaziyete dönebilmektedir.

Aketch vd. (2012) araştırmalarında, çalışanların iş-yaşam kalitelerinin yüksek olmasının onların iş performanslarına, motivasyonlarına, iş memnuniyetlerine, iş tutumlarına ve bağl1lıklarına olumlu etki yaptığ1 sonucuna ulaşmıştır. (Pichler, 2009: 452)'e göre ise uzun çalışma saatlerine maruz kalan çalışanların bu yoğunluktan ötürü özel hayatlarına, ailelerine yeterli vakti ayıramaması, kendisinden beklenen taleplere yeteri kadar cevap verememesi işyaşam dengesinin bozulmasına yol açmaktadır. Aynı şekilde kendinden beklenen istekleri 
yerine getiren çalışanın iş yerindeki sorumluluğunu aksatması ve görevlerini yerine getirememesi de dengeyi bozmakta ve hem bireysel hem de örgütsel sorunların ortaya çıkmasına neden olmaktadır.

İş-yaşam dengesi sağlanamadığı durumlarda çalışan açısından, yaşadığı stresin psikolojik sonuçlarının yanında tıbbi anlamda müdahale gerektiren tansiyon, kalp, mide rahatsızlıkları gibi sorunlarla karşı karşıya kaldığı fizyolojik sonuçlar da bulunmaktadır (Quick vd., 1997: 72). Birçok çalışmada çalışanın üstesinden gelemediği sürekli bitkinlik ve yorgunluk gibi rahatsızlıklarda artışa neden olduğu görülmektedir (Allen vd., 2000: 300).

Çalışanın çevresine verdiği zararlar aile ile sınırlı kalmayıp işe de yansımakta iş kazalarında artış, şiddet eğiliminin artması gibi durumlara yol açmaktadır (Küçükusta, 2007: 61). Dengenin bozulmasından dolayı genel iyilik hali bozulan bireyin sigara, alkol, uyuşturucu gibi geçici olarak keyif veren ancak kalıcı olarak bedende tahribata yol açan zararlı maddeleri kullanım düzeyinin de arttığı belirtilmektedir (Delecta, 2011: 188).

Sürekli olarak iş ve yaşam dengesini sağlamaya çalışan ancak başarılı olamayan çalışan bir noktadan sonra fiziksel, duygusal ve zihinsel yorgunluk yaşamaktadır. Tükenmişlik sendromu denilen bu durumda çalışan, yaptığı işten ve yaşadığı hayattan fiziksel ve zihinsel anlamda tükenme hissi yaşamaktadır (Maslach, 1981: 101).

\section{YÖNTEM}

\subsection{Araştırmanın Amacı}

Araştırmanın temel amacı, üniversitelerde psikolojik sermayenin çalışanların örgütsel bağlılıkları üzerindeki etkilerini belirlemek ve çalışanların iş-yaşam dengelerinin bu iki faktör üzerindeki aracılık rolünü ortaya çıkarmaktır. Çalışanlar fiziksel ve zihinsel tutum ve davranışlarıyla örgütün amaçlarını gerçekleştirmesine en önemli katkıları sağlayan, örgütün değişmez parçalarıdır. Örgütün gelişmesi, hedeflerine ulaşabilmesi, rekabetçi üstünlük sağlayabilmesi psikolojik sermayesini geliştirmek ve ona yatırım yaparak ilerlemesini sağlamakla mümkün görünmektedir. Bu açıdan genelde eğitim kurumlarında özelde üniversitelerde görev yapmakta olan çalışanların örgüte katkılarını arttırabilmek amacıyla son zamanlarda literatürde yer almaya başlayan psikolojik sermaye kavramının incelenmesi elzemdir. Diğer taraftan çalışanların örgüte bağlılıklarının örgütün amaçlarına ulaşmasında önemli bir faktör olduğu literatürde çeşitli çalışmalar ile ortaya konulmuştur. Türkiye ve Kırgızistan'da psikolojik sermaye kavramının son yıllarda çalışılmaya başlanmasına rağmen halen istenilen düzeyde olmadığı göze çarpmaktadır. Bu açıdan bakıldığında psikolojik sermaye ve örgütsel bağlılık ilişkisini belirlemek ve çalışanların iş-yaşam düzeylerinin bu iki faktör üzerindeki aracılık etkisinin ne düzeyde olduğunu araştırmak bu çalışmanın temel amacını oluşturmaktadır.

Araştırmanın temel problemini de oluşturan psikolojik sermaye ile örgütsel bağlılık arasındaki ilişkide iş-yaşam dengesinin aracılık rolünü belirlemek için geliştirilen hipotezler şu şekildedir;

H1: Psikolojik sermaye çalışanın duygusal bağglilığını etkilemektedir.

H2: Psikolojik sermaye çalışanın devamlılık bağglilığını etkilemektedir.

H3: Psikolojik sermaye çalışanın normatif bağhlığını etkilemektedir. 
H4: İ̧s-yaşam dengesi çalışanların psikolojik sermayesi ve örgütsel bağhllı̆̆g arasındaki ilişkide aracılık etmektedir.

\subsection{Evren ve Örneklem}

Araştırma evrenini Kırgızistan-Türkiye Manas Üniversitesi akademik ve idari personeli oluşturmaktadır. Örneklem belirleme yöntemi olarak "tabakalı rastgele örnekleme" yöntemi kullanılmıştır. Bu yöntem, hakkında çıkarım yapılması istenen topluluğu oluşturan birimlerin belirli bir özelliğe göre ayrılması ve sonrasında örnekleme alınacak kişilerin tabakadaki kişi sayısına orantılı olarak seçilmesidir. Veri toplama aracı olarak, araştırmacı tarafından hazırlanmış olan anket formları ilgili yöntem esas alınarak üniversite bünyesinde ulaşılabilen tüm akademisyen ve idari personele uygulanmıştır. Üniversite personel dairesinden alınan listeye göre ilgili dönemde üniversitenin çalışan sayısı 674 kişidir. Veri toplama süreci sonunda akademik ve idari personelden toplamda 447 anket formu geri dönüşü gerçekleşmiştir. Toplanan anket formlarının 36 tanesi eksik bilgi içerdiğinden ya da hatalı doldurulmasından dolayı kullanılmamış ve analizlere dahil edilmemiştir. Eksik ya da hatalı doldurulanlar çıkarıldıktan sonra geriye kalan toplam 411 anket veri setini oluşturarak analiz edilmiştir.

\subsection{Veri Toplama Araçları}

Araştırmada veri toplama yöntemi olarak sosyal bilimler alanında en çok kullanılan yöntem olan anket yöntemi kullanılmıştır. Hazırlanan anket formu genel olarak 4 bölümden oluşmaktadır. Araştırmanın birinci bölümünde "kişisel bilgi formu" yer almaktadır. Bu bölümde personelin demografik özellikleri (cinsiyet, yaş, unvan, uyruk, medeni durum, çalışma yılı) ile ilgili sorular bulunmaktadır. Anket formunun ikinci bölümünde çalışanların iş-yaşam dengesini belirlemek amacıyla kullanılan "İş-Yaşam Dengesi Ölçeğine" ait 9 soru yer almaktadır. Çalışanların iş-yaşam dengesini belirlemek amacıyla Nguen ve Nguen tarafından (2011) geliştirilen ölçek kullanılmıştır. Bu ölçek üç alt boyuttan (yaşamsal ihtiyaçlar, ait olma ihtiyaçları, bilgi ihtiyaçları) oluşmaktadır.

Anket formunun üçüncü bölümünde çalışanların örgüte bağlllık düzeylerini ölçmek amacıyla 18 maddeden oluşan "Örgütsel Bağlılık Ölçeğine” yer verilmiştir. Araştırmanın bağımlı değişkeni olan çalışanların örgütsel bağlılık düzeyini belirlemek amacıyla bu alanda önemli ölçüde kabul gören Allen ve Meyer tarafından geliştirilen Örgütsel Bağlılık Ölçeği kullanılmıştır. Bu ölçek duygusal, devamlılık ve normatif bağlılı̆̆1 olmak üzere üç alt boyuttan oluşmaktadır. Araştırmada kullanılan anket formunun dördüncü bölümünü ise "Psikolojik Sermaye Ölçeği" oluşturmaktadır. İşgörenlerin psikolojik sermaye düzeylerini belirlemek amacıyla 4 boyuttan oluşan 24 ifade kullanılmıştır. Psikolojik sermaye düzeyini ölçmek için Luthans, Youseff ve Avolio tarafından (2007) geliştirilen ölçek kullanılmıştır. Psikolojik sermayenin alt boyutları ise şunlardır; öz yeterlilik boyutu, umut boyutu, iyimserlik boyutu ve dayanıklılık boyutu. İlgili ölçekler esas alınarak oluşturulup uygulanan anket formunda yer alan maddelerde 5'li Likert (1=Hiçbir Zaman, 2=Çok Nadir, 3=Bazen, 4=Çoğu Zaman, 5=Her Zaman) kullanılmıştır. Anket uygulaması neticesinde elde edilen veriler "SPSS 23.0" analiz programı ile analize tabi tutulmuş, ayrıca araştırma modelini oluşturan ilişskilerin ve aracılık ilişkisinin test edilmesi için IBM SPSS Amos v.24 programı aracılığıyla "Yapısal Eşitlik Modeli (YEM)" kullanılmıştır. 
Yapısal Eşitlik Modeli (YEM); literatürde belirli bir teoriye dayanmış olarak gözlemlenebilen ve gözlemlenemeyen değişkenlerin nedensel ve ilişkisel bir model içerisinde tanımlanmasına dayanmakta olan çok değişkenli bir istatistik yöntemi olarak tanımlanmaktadır. YEM'in birincil amacı bir ya da daha fazla bağımsız değişkenle bir ya da daha fazla bağımlı değişken arasındaki ilişki desenini (Ayyıldız ve Cengiz, 2016: 67; Balc1, 2016: 274) test etmektir. YEM, son yıllarda sosyal bilimler alanındaki çalışmalarda sıklıkla kullanılmaya başlanmıştır çünkü belirlenen değişkenler arasındaki doğrudan ve dolaylı ilişkileri tek bir model içerisinde gösterebilmektedir (Meydan ve Şeşen, 2015: 5-6). YEM, test edilen modelin elde edilen veriler için ne derece uygun olduğunu göstermekte olan "Uyum İndeksleri” olarak bilinen birtakım ölçütler sunmaktadır (Meydan ve Şeşen, 2015: 31).

\section{BULGULAR ve DEĞERLENDİRME}

\section{1. Ölçeklere İlişkin Bulgular}

\subsubsection{Psikolojik Sermaye Ölçeği}

Psikolojik Sermaye düzeyini ölçmek için Luthans, Youseff ve Avolio tarafından (2007) geliştirilen, Çetin ve Basım (2012) tarafından uygulanan "Psikolojik Sermaye ölçeği" kullanılmıştır. Kullanılan ölçekte 24 ifade bulunmaktadır. Ölçek kullanılmadan önce farklılaşmış örneklemlerde ve çevrelerde kullanılacağından dolayı Doğrulayıcı Faktör Analizi yapılmıştır. Psikolojik Sermaye ölçeğinden elde edilen puanların güvenirlik katsayısını belirlemek amacıyla Cronbach Alfa güvenirlik analizi yapılmıştır. Ölçeğin alt faktörlere ilişkin Cronbach Alfa güvenirlik katsayıları Tablo 1'de verilmiştir.

Tablo 1. Psikolojik Sermaye Ölçeği ve Alt Boyutlarının Cronbach Alpha Güvenirlik Katsayıları

\begin{tabular}{|c|c|c|}
\hline Boyut/Ölçek & Madde & Cronbach's Alpha Katsayısı \\
\hline İyimserlik & 4 & 0,579 \\
\hline Dayanılılık & 5 & 0,659 \\
\hline Umut & 6 & 0,696 \\
\hline Öz Yeterlilik & 6 & 0,767 \\
\hline Psikolojik Sermaye & 21 & 0,892 \\
\hline
\end{tabular}

Tablo 1'de Psikolojik Sermayenin bu çalışma kapsamında elde edilen alt boyutlarının Cronbach Alfa güvenirlik katsayıları verilmiştir. Elde edilen bulgulara göre; "iyimserlik" alt boyutunun "geliştirilen testin güvenirliği düşüktür" düzeyinde, "dayanıklılık", "umut", "öz yeterlilik" alt boyutlarının "geliştirilen test oldukça güvenilirdir." düzeyinde, ölçeğin genelinin ise "geliştirilen ölçek/test yüksek güvenirliğe sahiptir." düzeyinde olduğu görülmektedir. $\mathrm{Bu}$ verilerden yola çıkarak ölçeğin ve alt boyutlarının güvenirlik katsayılarının kabul edilebilir olduğu görülmektedir. Ölçekte yer alan 24 madde ve dört faktörlü yapı Doğrulayıcı Faktör Analizi (DFA) ile sınanmıştır. Yapılan bu çalışmada da özgün ölçekte yer alan 24 madde ve dört alt boyutun doğruluğunun tespit edilmesi amaçlanmıştır.

Psikolojik Sermaye Ölçeğine yapılan Doğrulayıcı Faktör Analizinde her bir maddenin faktör yük değeri incelenmiştir. Yapılan analizler sonucu 7. madde (bu iş yerinde işler asla benim istediğim şekilde yürümez), 8. madde (işimde bir terslik karşılaştığımda, onu atlatma konusunda sıkıntı yaşıyorum) ve 11. madde (eğer işimde bir şeyler benim için yanlış 
gidecekse, o şekilde gider) faktör yüklerinin düşüklüğü sebebiyle analizden çıkarılmıştır. Bunun dışında tüm maddelerin faktör yüklerinin 0,30'un üzerinde olduğu bulunmuştur. Yapılan analiz sonucunda, ölçeğin dört boyutta uyumlu olduğu ve ki-kare değerinin $\left(\chi^{2}=694,971, \mathrm{df}=169, \mathrm{p}=0,000\right)$ anlamlı olduğu görülmüştür. Ayrıca düzeltilmiş Ki-Kare değeri 4,112 bulunarak istenilen değer aralığında olduğu tespit edilmiştir.

\subsection{2. Örgütsel Bağlılık Ölçeği}

Allen ve Meyer (1990) tarafından geliştirilen “Örgütsel Bağl1lık Ölçeği” kullanılmıştır. Kullanılan ölçekte 18 ifade bulunmaktadır. Ölçek kullanılmadan önce farklılaşmış örneklemlerde ve çevrelerde kullanılacağından dolayı doğrulayıcı faktör analizi yapılmıştır. Örgütsel Bağlılık Ölçeğinden elde edilen puanların güvenirlik katsayısını belirlemek amacıyla Cronbach Alfa güvenirlik analizi yapılmıştır. Ölçeğin alt faktörlere ilişkin Cronbach Alfa güvenirlik katsayıları Tablo 2' de verilmiştir.

Tablo 2. Örgütsel Bağlılık Ölçeği ve Alt Boyutlarının Cronbach Alpha Güvenirlik Katsayıları

\begin{tabular}{|c|c|c|}
\hline Boyut/Ölçek & Madde & Cronbach's Alpha Katsayısı \\
\hline Duygusal Bağllık & $3,4,5,7$ & 0,736 \\
\hline Devamllık Bağllı̆̆ 1 & $15,16,17,18$ & 0,723 \\
\hline Normatif Bağlılık & $8,9,10,11,12$ & 0,751 \\
\hline Örgütsel Bağlılık & 13 & 0,707 \\
\hline
\end{tabular}

Tablo 2'de örgütsel bağlılı̆̆ın bu çalışma kapsamında elde edilen alt boyutlarının Cronbach Alfa güvenirlik katsayıları verilmiştir. Elde edilen bulgulara göre; "normatif bağlılık", "duygusal bağlılık" ve "devamlılık bağlılı̆̆ı" alt boyutları ile ölçeğin genelinin "geliştirilen test oldukça güvenilirdir." olduğu görülmektedir. Bu verilerden yola çıkarak ölçeğin ve alt boyutlarının güvenirlik katsayılarının kabul edilebilir olduğu görülmektedir.

Örgütsel Bağlılık Ölçeğine yapılan Doğrulayıcı Faktör Analizinde her bir maddenin faktör yük değeri incelenmiştir. Maddenin faktör yük değerinin en az 0,30 ve üzeri bir yük değerine sahip olması gerektiği bilinmektedir. Yapılan analizler sonucu 1. madde (çalışma hayatımın geri kalan kısmını bu işletmede geçirmek beni çok mutlu eder.), 2. madde (işyerindeki sorunları kendi sorunlarımmış gibi hissederim.), 6. madde (bu işyerinin benim için önemli bir kişisel anlamı var.), 13. madde (bir insanın çalıştığı iş yerine daima sadık kalması gerektiğine inanmiyorum.) ve 14. madde (sürekli işyeri değiştirmek bana ahlak dışı görünmüyor.) faktör yüklerinin düşüklüğü sebebiyle analizden çıkarılmıştır. Bunun dışında tüm maddelerin faktör yüklerinin 0,30'un üzerinde olduğu görülmektedir.

Ölçekte yer alan 18 madde ve üç faktörlü yapı Doğrulayıcı Faktör Analizi (DFA) ile sınanmıştır. Yapilan bu çalışmada da özgün ölçekte yer alan 18 madde ve üç alt boyutun doğruluğunun tespit edilmesi amaçlanmıştır. Yapılan analiz sonucunda, ölçeğin üç boyutta uyumlu olduğu ve ki-kare değerinin $(\chi 2=111,753, d f=57, p=0,00)$ anlamlı olduğu görülmüştür. Ayrıca düzeltilmiş ki-kare değeri 1,961 bulunarak istenilen değer aralığında olduğu tespit edilmiştir.

\subsection{3. İş-Yaşam Dengesi Ölçeği}

İş-yaşam dengesini ölçmek amacıyla Nguen ve Nguen (2011) tarafından geliştirilen "İşYaşam Dengesi Ölçeği” kullanılmıştır. Ölçek kullanılmadan önce farklılaşmış örneklemlerde 
ve çevrelerde kullanılacağından dolayı doğrulayıcı faktör analizi yapılmıştır. İş-Yaşam Dengesi Ölçeğinden elde edilen puanların güvenirlik katsayısını belirlemek amacıyla Cronbach Alfa güvenirlik analizi yapılmıştır. Ölçeğin alt faktörlerine ilişkin Cronbach Alfa güvenirlik katsayıları Tablo 3'te verilmiştir.

Tablo 3. İş-Yaşam Dengesi Ölçeği ve Alt Boyutlarının Cronbach Alpha Güvenirlik Katsayıları

\begin{tabular}{|c|c|c|}
\hline Boyut/Ölçek & Madde & Cronbach's Alpha Katsayısı \\
\hline Yaşamsal & $1,2,3$ & 0,683 \\
\hline Ait Olma & $4,5,6$ & 0,467 \\
\hline Bilgi & $7,8,9$ & 0,875 \\
\hline İş-Yaşam Dengesi & $\mathbf{1 , 2 , \ldots , 9}$ & $\mathbf{0 , 8 3 7}$ \\
\hline
\end{tabular}

Tablo 3'te iş-yaşam dengesinin bu çalışma kapsamında elde edilen alt boyutlarının Cronbach Alfa güvenirlik katsayıları verilmiştir. Cronbach Alpha 0,00-1,00 arasında değer almaktadır (Cronbach, 1951: 302'den akt: Yaşar, 2014: 63). Elde edilen bulgulara göre; "ait olma" alt boyutunun "geliştirilen testin güvenirliği düşüktür" düzeyinde, "yaşamsal" alt boyutunun "geliştirilen test oldukça güvenilirdir." Düzeyinde ve "bilgi" alt boyutunun ve ölçeğin genelinin güvenirliği ise "geliştirilen ölçek/test yüksek güvenirliğe sahiptir" düzeyinde olduğu görülmektedir. Bu verilerden yola çıkarak ölçeğin ve alt boyutlarının güvenirlik katsayılarının kabul edilebilir olduğu görülmektedir.

Yapılan analizler sonucu tüm maddelerin faktör yüklerinin 0,30 değerinin üzerinde olduğu, ölçeğin üç boyutta uyumlu olduğu ve ki-kare değerinin $(\chi 2=125,549, \mathrm{df}=24, \mathrm{p}=0,00)$ anlamlı olduğu görülmüştür. Ayrıca düzeltilmiş ki-kare değeri 3,267 bulunarak istenilen değer aralığında olduğu tespit edilmiştir.

\subsection{Demografik Özelliklere İlişkin Bulgular}

Araştırmaya katılan çalışanların \% 54'ünü (222) erkekler, \% 46'sını (189) ise kadınlar oluşturmaktadır. Katılımcıların \% 76,2' sinin (313) evli ve \% 23,8'inin (98) ise bekâr olduğu, \% 68,1'inin (280) Kırgızistan Cumhuriyeti, \% 29,7'sinin (122) Türkiye Cumhuriyeti ve \% 2,2'sinin (9) ise diğer ülke vatandaşı olduğu anlaşılmıştır.

Katılımcıların \% 2,2'sinin (9) 21-25 yaş aralığında, \% 34,8'inin (143) 26-35 yaş aralığında, \% 38,4'inin (158) 34-45 yaş aralığında, \% 16,3'ünün (67) 46-55 yaş aralığında ve \% 8,3'ünün (34) ise 56 ya da daha yukarı bir yaşta olduğu görülmektedir. Ayrıca katılımcıların \% 40,4'ünün (166) idari personel, \% 59,6' sının (411) ise akademik personel olduğu, akademik personelin \% 11,7'sinin (29) Prof. Dr. olarak, \% 12,1'inin (30) Doç. Dr. olarak, \% 12,9'unun (32) Yrd. Doç. Dr. olarak, \% 24,6'sının (61) Öğr. Gör. olarak, \% 10,9'unun (27) Arş. Gör. olarak, \% 23,4'ünün (58) Okutman olarak ve \% 4'ünün (8) ise üniversite bünyesinde Uzman kadrosunda çalıştığını göstermektedir.

Katılımcların \% 35'i (144) 1-5 yıl arasında, \% 29,2'si (120) 6-10 yıl arasında, \% 21,4'ü (88) 1115 yıl arasında, \% 11,2'si (46) 16-20 yıl arasında, \% 2,9'u (12) 21-25 yıl arasında söz konusu üniversitede çalıştığını belirtmiştir. Ayrıca \% 15,1'i (62) 1-5 yıl, \% 20,2'si (83) 6-10 yıl, \% 22,6's1 (93) 11-15 yıl, \% 20,7'si (85) 16-20 yıl, \% 9'u (37) 21-25 yıl ve \% 12,4'ü (51) ise 26 yıldan fazla bir süredir iş hayatında bulunduğunu belirtmiştir. 
Demografik veriler incelendiğinde çalışmaya katılanların çoğunluğunu erkeklerin (\% 54) ve evlilerin $(\% 76,2)$ oluşturduğu, Kırgızistan vatandaşı olduğu (\% 68,1), 36-45 yaş aralığında bulunduğu (\% 38,4) ve 1-5 yıl arasında (\% 35) bir süredir ilgili üniversitede çalışan kişilerden oluştuğu görülmektedir. İş hayatında geçirdikleri toplam sürenin çoğunlukla 11-15 yıl arası (\% 22,6) olduğu ortaya çıkmıştır. Araştırmaya katılan akademisyenlerin $(\% 59,6)$ idari personelden fazla olduğu ve çoğunluğunu öğretim görevlilerinin $(\% 24,6)$ oluşturduğu anlaşılmaktadır.

\subsection{Araştırma Modelinin YEM (Yapısal Eşitlik Modeli) ile Test Edilmesi}

Psikolojik sermayenin örgütsel bağlılık üzerindeki etkisinde iş-yaşam dengesinin aracılık rolünün ortaya çıkarılması için Baron ve Kenny (1986) tarafından geliştirilen yöntem kullanılarak aracılık etkisi analizleri yapılmıştır. Aracılık etkisinin bu yöntem sayesinde ortaya çıkarılabilmesi için 4 koşulun sağlanması gerektiği belirtilmiştir. Bu koşullar;

1. Bağımsız değişkenin (psikolojik sermaye), bağımlı değişken (örgütsel bağlılık) üzerinde anlamlı bir etkisi olmalıdır.

2. Bağımsız değişkenin (psikolojik sermaye), aracı değişken (iş-yaşam dengesi) üzerinde anlamlı bir etkisi olmalıdır.

3. Aracı değişkenin bağımlı değişken üzerinde anlamlı bir etkisi olmalıdır.

4. Aracı değişken bağımsız değişkenle birlikte modele dâhil edildiğinde; Bağımsız değişkenin bağımlı değişken üzerindeki etkisi anlamlı şekilde azalırsa "kısmi aracılık" etkisinden, bağımsız değişkenin bağımlı değişken üzerindeki etkisi anlamsız hale geliyorsa "tam aracılık" etkisi söz konusu olmaktadır.

Araştırmada test edilen modelde; öz yeterlilik, umut, iyimserlik, dayanıklılık alt boyutların oluşan psikolojik sermaye ölçeği bağımsız (egzojen) değişken olarak yer almaktadır. Örgütsel bağlılığın alt boyutları olan devamlılık bağlılı̆̆ı, normatif bağlılık, duygusal bağlılık bağımlı (endojen) değişken olarak yer almaktadır. Yapılan test sonuçlarına göre ortaya çıkan modelin uyum iyiliği değerleri Tablo 4.'te gösterilmiştir.

Tablo 4. Psikolojik Sermaye Algısının Örgütsel Bağlılık Alt Boyutları Üzerindeki Etkisine Ait Yapısal Eşitlik Modeli Uyum Değerleri

\begin{tabular}{|c|c|c|c|}
\hline Uyum Ölçüleri & İyi Uyum & Kabul Edilebilir Uyum & Modelin Uyum Değerleri \\
\hline$\left(\chi^{2} / \mathrm{sd}\right)$ & $\leq 3$ & $\leq 4-5$ & 2,23 \\
\hline GFI & $\geq 0,90$ & $0,89-0,85$ & 0,93 \\
\hline CFI & $\geq 0,96$ & $0,90-0,95$ & 0,93 \\
\hline AGFI & $\geq 0,90$ & $0,89-0,80$ & 0,91 \\
\hline RMSEA & $\leq 0,05$ & $0,06-0,08$ & 0,055 \\
\hline
\end{tabular}

Modele ilişkin ( $\chi 2 /$ sd) değeri 2,23 çıkmış olup iyi uyumu işaret etmektedir. Benzer şekilde GFI CFI, AGFI, RMSEA değerleri de iyi uyum olduğunu göstermektedir. Test edilen yapısal eşitlik modelinin toplanan verilerle iyi uyum gösterdiği anlaşılmaktadır. Test edilen model Şekil 1'de gösterilmiştir. 


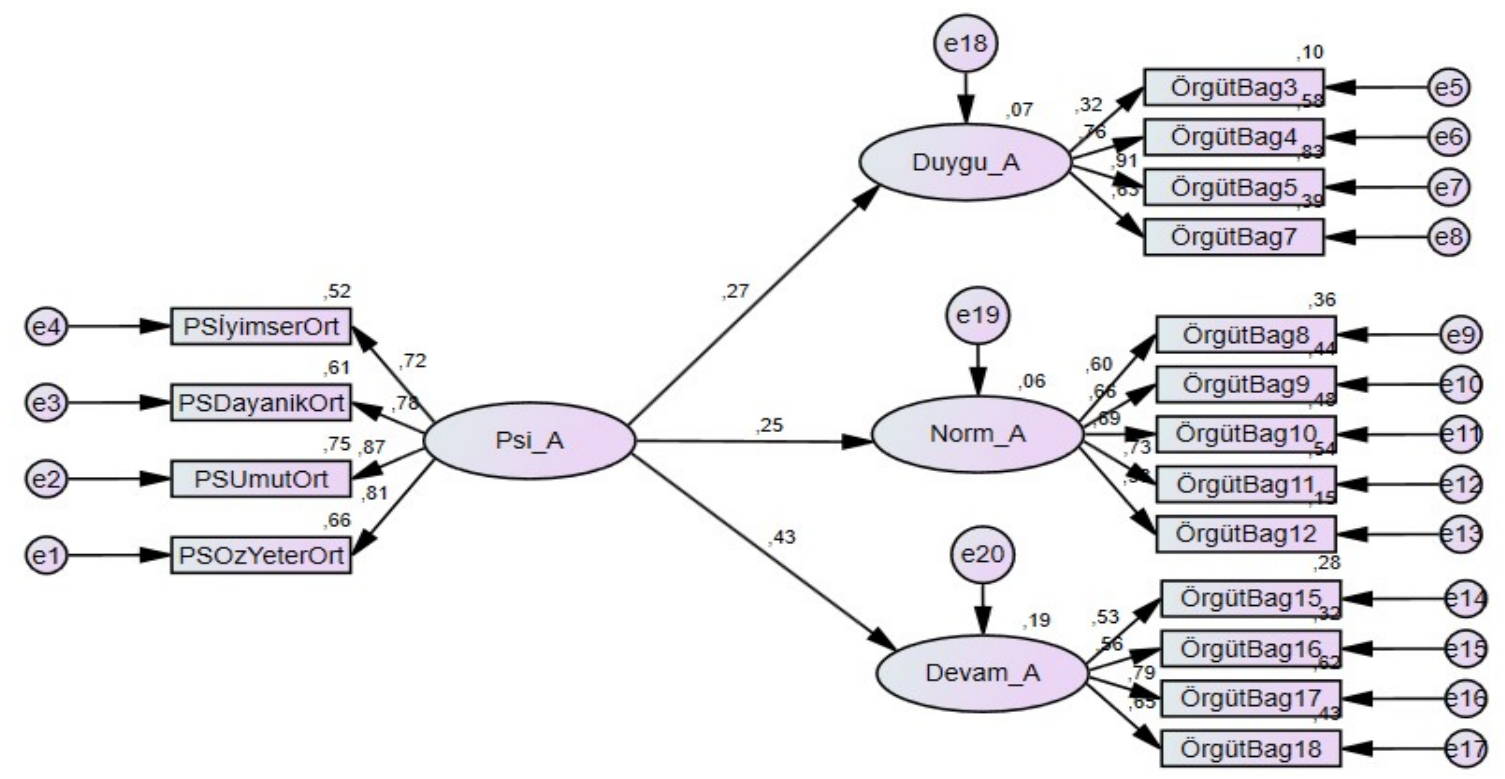

Şekil 1. Psikolojik Sermaye Algısının Örgütsel Bağlllık Alt Boyutları Üzerindeki Etkisine Ait Yapısal Eşitlik Modeli

Şekil 1.'de gösterilen yapısal eşitlik modeline göre, değişkenler arasındaki standardize edilmiş $\beta$ katsayıları, standart hata, $\mathrm{p}$ değeri ve R2 değerleri Tablo 5'te gösterilmiştir.

Tablo 5. Psikolojik Sermaye Algısının Örgütsel Bağlılık Alt Boyutları Üzerindeki Etkisine Ait Yapısal Eşitlik Modelinde Yer Alan Değişkenlere Ait Yol Katsayıları

\begin{tabular}{|ccccccc|}
\hline $\begin{array}{c}\text { Bağımlı } \\
\text { Değişken }\end{array}$ & Bağımsız Değişken & $\begin{array}{c}\text { Standardize } \\
\text { Beta }(\boldsymbol{\beta})\end{array}$ & $\begin{array}{c}\text { Standart } \\
\text { Hata }\end{array}$ & $\mathbf{p}$ & $\mathbf{R}^{\mathbf{2}}$ \\
\hline Duygusal Bağllık & $\leftarrow$ & Psikolojik Sermaye & 0,267 & 0,068 & ${ }^{* * *}$ & 0,071 \\
\hline Normatif Bağlılık & $\leftarrow$ & Psikolojik Sermaye & 0,251 & 0,108 & ${ }^{* * *}$ & 0,063 \\
\hline Devamllık Bağllığ & $\leftarrow$ & Psikolojik Sermaye & 0,433 & 0,089 & ${ }^{* * *}$ & 0,188 \\
\hline
\end{tabular}

${ }_{* * *} \mathrm{p}<0,001$

Elde edilen veriler incelendiğinde, çalışanların psikolojik sermaye düzeylerinin örgütsel bağlılık alt boyutlarından duygusal bağlılık $(\beta=0,267 ; p<0,001)$, normatif bağlılık $(\beta=0,251$; $\mathrm{p}<0,001)$ ve devamlılık bağlılığ1 $(\beta=0,433 ; p<0,001)$ üzerinde pozitif yönlü ve anlamlı bir etkisinin olduğu anlaşılmıştır. Psikolojik sermaye düzeyi arttıkça çalışanların örgütsel bağlılığın arttığı gözlenmiştir. Psikolojik sermaye düzeyi duygusal bağlılıktaki değişimin \% 7'sini, normatif bağlılıktaki değişimin \%6'sını ve devamlılık bağlılığındaki değişimin \% 19 'unu açıklamaktadır.

Bir sonraki adımda (Koşul 2) test edilen modelde; öz yeterlilik, umut, iyimserlik, dayanıklılık alt boyutların oluşan psikolojik sermaye bağımsız (egzojen) değişken olarak yer almaktadır. İş-yaşam dengesi alt boyutları olan yaşamsal ihtiyaçlar, ait olma ihtiyacı ve bilgi ihtiyacı (endojen) değişken olarak yer almaktadır. Yapılan test sonuçlarına göre ortaya çıkan modelin uyum iyiliği değerleri Tablo 6.'da gösterilmiştir. 
Tablo 6. Psikolojik Sermaye Algısının İş-Yaşam Dengesi Alt Boyutları Üzerindeki Etkisine Ait Yapısal Eşitlik Modeli Uyum Değerleri

\begin{tabular}{|c|c|c|c|}
\hline Uyum Ölçüleri & İyi Uyum & Kabul Edilebilir Uyum & Modelin Uyum Değerleri \\
\hline$\left(\chi^{2} / s d\right)$ & $\leq 3$ & $\leq 4-5$ & 3,26 \\
\hline GFI & $\geq 0,90$ & $0,89-0,85$ & 0,93 \\
\hline CFI & $\geq 0,96$ & $0,90-0,95$ & 0,94 \\
\hline AGFI & $\geq 0,90$ & $0,89-0,80$ & 0,89 \\
\hline RMSEA & $\leq 0,05$ & $0,06-0,08$ & 0,074 \\
\hline
\end{tabular}

Modele ilişkin ( $\left.\chi^{2} / \mathrm{sd}\right)$ değeri 3,26 çıkmış olup CFI, AGFI, RMSEA değerleri ile birlikte kabul edilebilir uyum değerinde olduğunu göstermekte, GFI ise iyi uyum olduğunu belirtmektedir. Test edilen yapısal eşitlik modelinin toplanan verilerle çoğunlukla kabul edilebilir uyum gösterdiği anlaşılmaktadır. Test edilen model Şekil 2.' de gösterilmiştir.

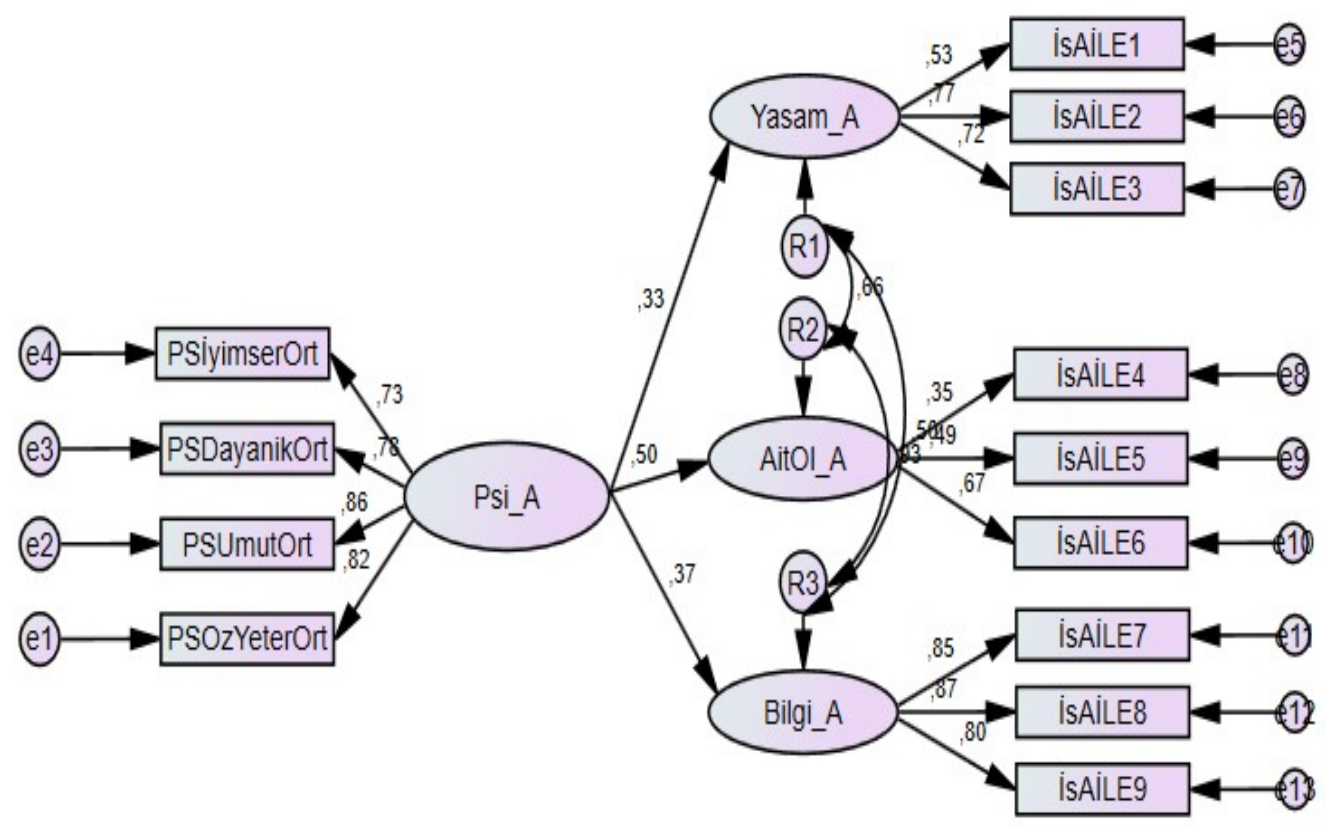

Şekil 2. Psikolojik Sermaye Algısının İş-Yaşam Dengesi Alt Boyutları Üzerindeki Etkisine Ait Yapısal Eşitlik Modeli

Şekil 2.'de gösterilen yapısal eşitlik modeline göre, değişkenler arasındaki standardize edilmiş $\beta$ katsayıları, standart hata, $p$ değeri ve R2 değerleri Tablo 7'da gösterilmiştir.

Tablo 7. Psikolojik Sermaye Algısının İş-Yaşam Dengesi Alt Boyutları Üzerindeki Etkisine Ait Yapısal Eşitlik Modelinde Yer Alan Değişkenlerin Yol Katsayıları

\begin{tabular}{|ccccccc|}
\hline Bağımlı Değişken & $\begin{array}{c}\text { Bağımsız } \\
\text { Değişken }\end{array}$ & $\begin{array}{c}\text { Standardize } \\
\text { Beta }(\boldsymbol{\beta})\end{array}$ & $\begin{array}{c}\text { Standart } \\
\text { Hata }\end{array}$ & $\mathbf{p}$ & $\mathbf{R}^{2}$ \\
\hline $\begin{array}{c}\text { Yaşamsal } \\
\text { İhtiyaçlar }\end{array}$ & $\leftarrow$ & Psikolojik Sermaye & 0,328 & 0,082 & $* * *$ & 0,107 \\
\hline Ait Olma İhtiyacı & $\leftarrow$ & Psikolojik Sermaye & 0,497 & 0,063 & $* * *$ & 0,247 \\
\hline Bilgi İhtiyacı & $\leftarrow$ & Psikolojik Sermaye & 0,368 & 0,106 & $* * *$ & 0,135 \\
\hline
\end{tabular}

${ }_{* * *} \mathrm{p}<0,001$ 
Elde edilen veriler incelendiğinde, çalışanların psikolojik sermaye düzeylerinin iş-yaşam dengesi alt boyutlarından yaşamsal ihtiyaçlar $(\beta=0,328$; $p<0,001)$, ait olma ihtiyacı $(\beta=0,497$; $\mathrm{p}<0,001)$ ve bilgi ihtiyacı $(\beta=0,368 ; \mathrm{p}<0,001)$ üzerinde pozitif yönlü ve anlamlı bir etkisinin olduğu anlaşılmıştır. Psikolojik sermaye düzeyi arttıkça çalışanların iş-yaşam dengesinin arttığ1 gözlenmiştir. Psikolojik sermaye düzeyi yaşamsal ihtiyaçlardaki değişimin \% 11'ini, ait olma ihtiyacındaki değişimin \% 25'ini ve bilgi ihtiyacındaki değişimin \% 14'ünü açıklamaktadır.

Bir sonraki adımda (Koşul 3) iş-yaşam dengesinin, psikolojik sermaye ile örgütsel bağlılık arasındaki ilişkide aracılık rolü test edilmiştir. Test edilen modelde; öz yeterlilik, umut, iyimserlik, dayanıklılık alt boyutların oluşan psikolojik sermaye ölçeği bağımsız (egzojen) değişken olarak yer almaktadır. Örgütsel bağllık (endojen) değişken ve iş-yaşam dengesi ise aracı değişken olmaktadır. Yapılan test sonuçlarına göre ortaya çıkan modelin uyum iyiliği değerleri Tablo 8.'de gösterilmiştir.

Tablo 8. Psikolojik Sermaye ile Örgütsel Bağlllık Arasındaki İlişkide İş-Yaşam Dengesinin Aracılık Rolünü Belirlemek İçin Test Edilen Yapılan Yapısal Eşitlik Modeline Ait Uyum Değerleri

\begin{tabular}{|c|c|c|c|}
\hline Uyum Ölçüleri & İyi Uyum & Kabul Edilebilir Uyum & Modelin Uyum Değerleri \\
\hline$\left(\chi^{2} / \mathrm{sd}\right)$ & $\leq 3$ & $\leq 4-5$ & 3,02 \\
\hline GFI & $\geq 0,90$ & $0,89-0,85$ & 0,90 \\
\hline CFI & $\geq 0,96$ & $0,90-0,95$ & 0,87 \\
\hline AGFI & $\geq 0,90$ & $0,89-0,80$ & 0,86 \\
\hline RMSEA & $\leq 0,05$ & $0,06-0,08$ & 0,070 \\
\hline
\end{tabular}

Modele ilişkin ( $\chi 2 / \mathrm{sd})$ değeri 3,02 çıkmış olup GFI değeri ile birlikte iyi uyumu gösterirken, diğer yandan CFI, AGFI, RMSEA değerleri ise kabul edilebilir uyum olduğunu göstermektedir. Test edilen yapısal eşitlik modelinin toplanan verilerle çoğunlukla kabul edilebilir uyum gösterdiği anlaşılmaktadır. Test edilen model Şekil 3.'te gösterilmiştir.

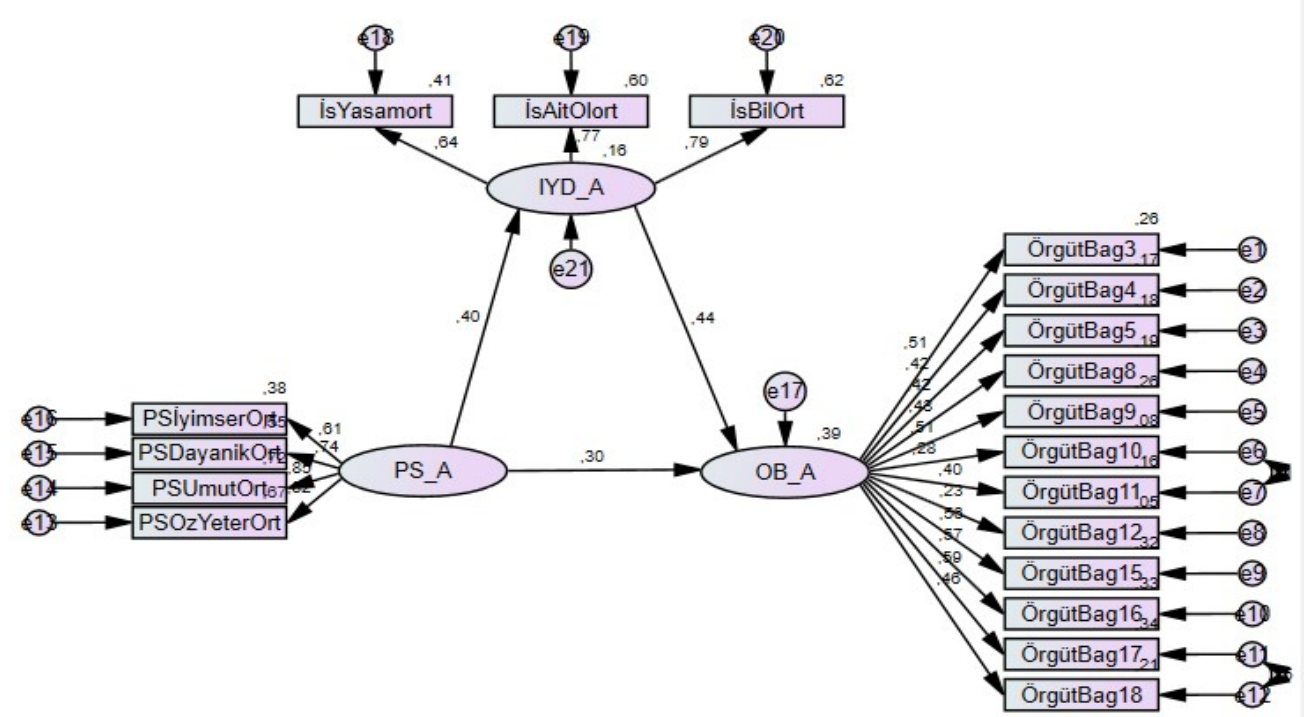

Şekil 3. Psikolojik Sermaye ile Örgütsel Bağlılık Arasındaki İlişkide İş-Yaşam Dengesinin Aracılık Rolünü Belirlemek için Test Edilen Yapısal Eşitlik Modeli 
Şekil 3.'te gösterilen yapısal eşitlik modeline göre, değişkenler arasındaki standardize edilmiş $\beta$ katsayıları, standart hata, p değeri ve R2 değerleri Tablo 9' da gösterilmiştir.

Tablo 9. Aracılık Rolünü Belirlemek İçin Yapılan Testte Yer Alan Değişkenlerin Yol Katsayıları

\begin{tabular}{|c|c|c|c|c|c|c|c|}
\hline \multicolumn{5}{|c|}{ Aracılık Modeli } & \multirow{2}{*}{$\begin{array}{c}\begin{array}{c}\text { Direkt Etki } \\
\text { (Aracı } \\
\text { Olmadan) }\end{array} \\
0,330^{* * *}\end{array}$} & \multirow{2}{*}{$\begin{array}{c}\begin{array}{c}\text { Direkt Etki } \\
\text { (Aracı ile } \\
\text { Birlikte) }\end{array} \\
0,288^{* * *}\end{array}$} & \multirow{2}{*}{$\begin{array}{c}\begin{array}{c}\text { Dolayl } \\
\text { Etki }\end{array} \\
0,184^{* *}\end{array}$} \\
\hline $\begin{array}{l}\text { Psikolojik } \\
\text { Sermaye }\end{array}$ & $\rightarrow$ & $\begin{array}{l}\text { İş-Yaşam } \\
\text { Dengesi }\end{array}$ & $\rightarrow$ & $\begin{array}{l}\text { Örgütsel } \\
\text { Bağllllkk }\end{array}$ & & & \\
\hline
\end{tabular}

*** $\mathrm{p}<0,001{ }^{* *} \mathrm{p}<0,010$

Elde edilen veriler incelendiğinde, çalışanların psikolojik sermaye algılarının, iş-yaşam dengesi aracı değişken olarak modelde yer almadığı zaman, örgütsel bağlllık üzerinde doğrudan pozitif yönlü ve anlamlı bir etkisinin bulunduğu anlaşılmaktadır $(\beta=0,332$; $\mathrm{p}<0,001)$. İş-yaşam dengesi aracı değişken olarak modele eklendiğinde ise, psikolojik sermayenin örgütsel bağlılık üzerindeki doğrudan etkisinin bir miktar azaldığı gözlenmiştir $(\beta=0,288 ; p<0,001)$. Psikolojik sermaye ve iş-yaşam dengesi bir araya gelerek örgütsel bağllıktaki değişimin \% 39,8'ini açıklamaktadır. Kişinin psikolojik sermaye düzeyi ve işyaşam dengesi birlikte örgütsel bağlllık üzerinde önemli bir etkiye sahiptir.

Hesaplanan dolaylı etki incelendiğinde, psikolojik sermaye düzeyinin örgütsel bağlılık üzerindeki etkisinin bir kısmının iş-yaşam dengesi üzerinden gerçekleşmeye başladığ belirlenmiştir $(\beta=0,184 ; p<0,01)$. Test incelendiğinde doğrudan etki değerlerinin bir miktar azalmasına rağmen istatistiksel olarak anlamlı kalmaya devam etmesi sonucu; psikolojik sermaye ile örgütsel bağlılık arasındaki ilişkide, iş-yaşam dengesinin kısmî aracı değişken rolü üstlendiği ortaya çıkarılmıştır.

SPSS AMOS 24 programı ile yapılan aracılık testlerinin doğruluğunu desteklemek amaciyla SPSS 23 üzerinden Process V2.16.3 eklentisi aracılığılla Sobel testi yapılmış ve söz konusu değişkenler arasında anlamlı bir aracılık olduğu desteklenmiştir $(p=0,00<0,05)$. Hayes $(2014)$ bootstrap yapılarak güven aralıklarının hesaplanmasının $p$ değerine göre güvenilir olduğunu belirtmiştir. Hesaplanan değerlerin arasında sıfır değeri yer almadığı takdirde aracılıktan söz edilebileceğini belirtmiştir. Yapılan testte, güven aralıklarının hesaplanması sonucu (BootLLCI =,0471 ve BootULCI = ,1308) aracilık etkisinin olduğu savı desteklenmiştir.

\section{SONUÇ VE ÖNERILER}

Çalışanların psikolojik sermaye algılarının örgütsel bağlılık alt boyutları üzerindeki etkisini ortaya çıkarmak amacıyla model oluşturulmuştur. Bu modelde öz yeterlilik, umut, iyimserlik, dayanıklılık alt boyutların oluşan psikolojik sermaye ölçeği bağımsız (egzojen) değişken olarak yer almaktadır. Örgütsel bağlılığın alt boyutları olan devamlılık bağlılığı, normatif bağlılık, duygusal bağlılık bağımlı (endojen) değişken olarak yer almaktadır. Çalışanların psikolojik sermaye düzeylerinin, örgütsel bağlılık alt boyutlarından duygusal bağlılık $(\beta=0,267 ; p<0,001)$, normatif bağlılık $(\beta=0,251 ; p<0,001)$ ve devamlılık bağl1lığ1 $(\beta=$ $0,433 ; p<0,001)$ üzerinde pozitif yönlü ve anlamlı bir etkisinin olduğu anlaşılmıştır. Psikolojik sermaye düzeyi arttıkça çalışanların örgütsel bağlılığının arttığı gözlenmiştir. Psikolojik sermaye düzeyi duygusal bağlılıktaki değişimin \% 7'sini, normatif bağlılıktaki değişimin \% 
6'sını ve devamlılık bağlılığındaki değişimin \% 19'unu açıklamaktadır. Üniversitede çalışan personelin psikolojik sermaye düzeylerini arttırmaya yönelik çalışmaların aynı zamanda personelin çalıştığı örgüte bağlılığını da arttıracağı söylenebilir. Araştırmadan elde edilen sonuçlar literatür ile karşılaştırıldığında, geçmişte psikolojik sermaye ile örgütsel bağlılık ilişkisini inceleyen çalışmalar ile paralel sonuçlara ulaşıldığı görülmektedir. $\mathrm{Bu}$ araştırmalarda hem psikolojik sermayenin hem de örgütsel bağlılı̆̆ın çeşitli alt boyutları arasında ilişki olduğu ortaya çıkarılmıştır (Luthans vd., 2007; Avey vd., 2011; Çetin, 2011; Ocak vd., 2016; Karacan, 2018; Uygungil ve İşcan, 2018).

Personelin psikolojik sermaye düzeylerinin iş-yaşam dengesi alt boyutları ile olan ilişkisini ortaya çıkarmak amacıyla bir model oluşturulmuştur. Test edilen modelde öz yeterlilik, umut, iyimserlik, dayanıklılık alt boyutların oluşan psikolojik sermaye bağımsız (egzojen) değişken olarak yer almaktadır. İş-yaşam dengesi alt boyutları olan yaşamsal ihtiyaçlar, ait olma ihtiyacı ve bilgi ihtiyacı (endojen) değişken olarak yer almaktadır. Personelin psikolojik sermaye düzeylerinin iş-yaşam dengesi alt boyutlarından yaşamsal ihtiyaçlar $(\beta=0,328$; $\mathrm{p}<0,001)$, ait olma ihtiyac1 $(\beta=0,497 ; \mathrm{p}<0,001)$ ve bilgi ihtiyac1 $(\beta=0,368 ; \mathrm{p}<0,001)$ üzerinde pozitif yönlü ve anlamlı bir etkisinin olduğu anlaşılmıştır. Psikolojik sermaye düzeyi arttıkça çalışanların iş-yaşam dengesinin arttığı gözlenmiştir. Psikolojik sermaye düzeyi yaşamsal ihtiyaçlardaki değişimin \% 11'ini, ait olma ihtiyacındaki değişimin \% 25'ini ve bilgi ihtiyacındaki değişimin \% 14'ünü açıklamaktadır. Yapılan çalışmaların devamı sağlanması durumda bu pozitif ilişkinin sürebileceği söylenebilir. Psikolojik sermaye düzeyini arttırıcı faktörlerin yönetim tarafından sağlanması halinde ise çalışanların hem iş hayatındaki görevleri yerine getirebileceği hem de iş dışı faaliyetlerine, kişisel hobilerine, aile ve yakın çevresine daha fazla zaman ayırarak iş-yaşam dengesinin daha üst düzeye çıkarılabileceği sonucu ortaya çıkmaktadır. Geçmişte psikolojik sermaye ile bağlantılı kavramlar ile işyaşam dengesi ilişkisini ele alan çalışmalara paralel sonuçların elde edildiği söylenebilir (Aketch vd., 2012; Sen ve Hooja, 2015; Güleryüz, 2016).

Çalışanların iş-yaşam dengesi düzeyinin örgütsel bağlılıkları ile ilişkisini tespit etmek amacıyla bir model oluşturulmuştur. Test edilen modelde yaşamsal ihtiyaçlar, ait olma ihtiyacı, bilgi ihtiyacı alt boyutlarından oluşan iş-yaşam dengesi bağımsız (egzojen) değişken olarak yer almaktadır. Örgütsel bağlılığın alt boyutları olan devamlılık bağ lılığı, normatif bağlılık, duygusal bağlılık bağımlı (endojen) değişken olarak yer almaktadır. Çalışanların işyaşam dengesi düzeylerinin, örgütsel bağlllık alt boyutlarından duygusal bağlılık $(\beta=0,246$; $\mathrm{p}<0,001)$, normatif bağlılık $(\beta=0,233 ; \mathrm{p}<0,001)$ ve devamlılık bağl1lı̆̆1 $(\beta=0,547 ; p<0,001)$ üzerinde pozitif yönlü ve anlamlı bir etkisinin olduğu anlaşılmıştır. İş-yaşam dengesi düzeyi arttıkça çalışanların örgütsel bağlılığının arttığı gözlenmiştir. İş-yaşam düzeyi duygusal bağlılıktaki değişimin \% 6'sını, normatif bağlılıktaki değişimin \% 5'ini ve devamlılık bağlılığındaki değişimin \% 30'unu açılamaktadır. İş-yaşam dengesini sağlayamayan bireylerin bu dengeyi sağlayabilmek için işten ayrılma kararı vermesi bilinen bir durumdur. Test sonuçlarında görüldüğü üzeri iş-yaşam dengesini arttırıcı çalışmalar yapılması örgütsel bağlılığın artmasına sebep olmaktadır. Örgütsel bağlılığın alt boyutlarına bakıldığında, işyaşam dengesi en çok çalışanın devamlılık bağlılı̆̆ üzerinde etkilidir. İş-yaşam dengesini sağlayabilen çalışan, mutlu ve huzurlu bir iş ve aile hayatının devamını sağlayabilmek için mevcut örgütte çalışmaya devam etmektedir. Araştırma sonuçları literatür ile benzer sonuçlar elde edildiğini göstermektedir. Örgütsel bağlılık alt boyutları ile iş-yaşam dengesi 
alt boyutları arasında anlamlı ilişkiler olduğu geçmişte yapılan çalışmalarda ortaya konulmuştur (Malone ve Issa, 2013; Azeem ve Akhtar, 2014; Korkmaz ve Erdoğan, 2014; Pradhan vd., 2016; Kim ve Ryu, 2017).

Psikolojik sermaye ile çalışanların örgütsel bağlılıkları arasındaki ilişkide iş-yaşam dengesinin aracılık rolünü belirlemek amacıyla yapısal eşitlik modeli kurulmuştur. Test edilen modelde öz yeterlilik, umut, iyimserlik, dayanıklılık alt boyutların oluşan psikolojik sermaye bağımsız (egzojen) değişken olarak yer almaktadır. Örgütsel bağlılığın alt boyutları olan devamlılık bağlılığı, normatif bağlılık, duygusal bağlılık bağımlı (endojen) değişken olarak yer almaktadır. İş-yaşam dengesi alt boyutları olan yaşamsal ihtiyaçlar, ait olma ihtiyacı ve bilgi ihtiyacı ise aracı değişken olarak yer almaktadır. Üniversitede çalışan personelin, psikolojik sermaye algılarının, iş-yaşam dengesi aracı değişken olarak modelde yer almadığı zaman, örgütsel bağlılık üzerinde doğrudan pozitif yönlü ve anlamlı bir etkisinin bulunduğu anlaşılmaktadır $(\beta=0,332 ; p<0,001)$. İş-yaşam dengesi aracı değişken olarak modele eklendiğinde ise, psikolojik sermayenin örgütsel bağlllık üzerindeki doğrudan etkisinin bir miktar azaldığı gözlenmiştir $(\beta=0,288 ; p<0,001)$. Psikolojik sermaye ve iş-yaşam dengesi bir araya gelerek örgütsel bağllıktaki değişimin \% 39,8'ini açıklamaktadır. Kişinin psikolojik sermaye düzeyi ve iş-yaşam dengesi birlikte örgütsel bağlılık üzerinde önemli bir etkiye sahiptir.

Hesaplanan dolaylı etki incelendiğinde, psikolojik sermaye düzeyinin örgütsel bağlllık üzerindeki etkisinin bir kısmının iş-yaşam dengesi üzerinden gerçekleşmeye başladığı belirlenmiştir $(\beta=0,184 ; p<0,01)$. Çalışanın psikolojik sermaye düzeyini ve iş-yaşam düzeyini arttırıcı yöntem ve tekniklerin kullanılması sonucu kişinin çalıştığı örgüte bağlılığının da artacağı söylenebilir.

Gerçekleştirilen analizler neticesinde, doğrudan etki değerlerinin bir miktar azalmasına rağmen istatistiksel olarak anlamlı kalmaya devam etmesi sonucu; psikolojik sermaye ile örgütsel bağlılık arasındaki ilişkide, iş-yaşam dengesinin kısmî aracı değişken rolü üstlendiği ortaya çıkarılmıştır. Literatürde psikolojik sermaye ile örgütsel bağlılık ilişkisini inceleyen çalışmalar ayrıca psikolojik sermaye, örgütsel bağlılık ve iş-yaşam dengesi üzerine tek ilişkili ya da ikili ilişkilendirmeye dayalı pek çok araştırma yapılmıştır. Ancak, bağımsız değişken olarak ele alınan psikolojik sermayenin, bağımlı değişken olan örgütsel bağlılık ile ilişkisinde iş-yaşam dengesinin aracı rolüne yönelik olan bu çalışmanın literatüre önemli bir katkı sağlayabileceği düşünülebilir. Bu bağlamda, çalışmanın temel araştırma sorusuna ilişkin olarak; psikolojik sermayenin çalışanın örgütsel bağlılığını açıklama hususunda doğrudan etkilerinin yanında, kişilerin iş-yaşam dengesi algılarının aracılık ettiği dolaylı etkilerinin de bulunduğu sonucunda ulaşılmıştır.

Literatürde aracılık etkisini yapısal eşitlik modeli ile değişkenlerin arasındaki ilişkiye yönelik yapılan çalışmalarda çoğunlukla aracı değişkenin bağımlı ve bağımsız değişkenler arasındaki ilişkinin yönünü değiştirmediği, eğer pozitif yönlü bir ilişki varsa bunun devam ettiği, negatif yönlü ise negatif olarak kaldığı sonucuna ulaşılmıştır. Yapılan araştırmalarda genelde aracı değişkenin modele katılmasıyla birlikte bağımsız değişkenin bağımlı değişken üzerindeki etkisinin devam ettiği ancak bu etkinin gücünün azaldığ yani aracı değişkenin ilişkide kısmî aracılık rolü oynadığ 
bulgulara paralel sonuçlar vermesi sonraki zamanlarda yapılacak çalışmalar açısından önemli olduğu söylenebilir.

Kırgızistan ile Türkiye arasındaki ikili anlaşma sonucunda özel statülü devlet üniversitesi olarak Bişkek şehrinde kurulan üniversitede çalışmakta olan akademik ve idari personelin; psikolojik sermaye düzeylerinin örgütsel bağlılıkları üzerinde etkisinin olup olmadığı ile bu etki de iş-yaşam dengesinin aracılık etkisinin bulunup bulunmadığını tespit etmek üzere gerçekleştirilen bu araştırma sonucunda literatüre ve uygulamalara katkıda bulunabileceği söylenebilmektedir.

\section{KAYNAKÇA}

Aketch, J. R., Odera, O., Chepkuto, P. \& Okaka, O. (2012). Effects of quality of work life on job performance: Theoretical perspectives and literature review. Current Research Journal of Social Sciences, 4(5), 383-388.

Allen, T. D., Herst, D. E. L., Bruck, C. \& Sutton, M. (2000). Consequences associated with work-to-family conflict: A review and agenda for future research. Journal of Occupational Health Psychology, 5(2), 278-308.

Altan, S. ve Özpehlivan, M. (2018). Örgüt Kültürü, Psikolojik Sermaye ve Örgütsel Bağlllık Kavramları Arasındaki Etkileşim: Bilişim Sektöründe Uygulama. Turkish Studies, 13(18), 159-178.

Angle, H. L. \& Perry, J. L. (1981). An empirical assessment of organizational commitment and organizational effectiveness. Administrative Science Quarterly, 26, 1-13.

Avey, J. B., Luthans, F. \& Youssef, C. M. (2008). The additive value of positive psychological capital in predicting work attitudes and behaviors. Leadership Institute Faculty Publications, Paper 6, 1-42.

Avey, Reichard, R. J. \& Luthans, F. (2011). Meta-Analysis of the impact of positive psychological capital on employee attitudes, behaviors and performance. Human Recource Development Quarterly, 22(2), 127-152.

Ayyıldız, Cengiz, A. (2006). Pazarlama Modellerinin Testinde Kullanılabilecek Yapısal Eşitlik Modeli (YEM) Üzerine Kavramsal Bir İnceleme. Süleyman Demirel Üniversitesi İktisadi ve İdari Bilimler Fakültesi Dergisi, 11(2), 63-84.

Azeem, S. M., \& Akhtar, N. (2014). The influence of work life balance and job satisfaction on organizational commitment of healthcare employees. International Journal of Human Resource Studies, 4(2), 18-24.

Barnett, R. C. (1999). A new work-life model for the twenty first century. The Annals of the American Academy of Political and Social Science, 562(1), 143-158.

Baron, R. M. \& Kenny, D. A. (1986). The moderator-mediator variable distinction in social psychological research: conceptual, strategic, and statistical considerations. Journal of Personality and Social Psychology, 51(6), 1173.

Begenirbas, M. ve Turgut, E. (2016). Psikolojik Sermayenin Cạlışanların Yenilikç, Davranışlarına ve Performanslarına Etkileri: Savunma Sektöründe Bir Araştırma. Dokuz Eylül Üniversitesi İktisadi ve İdari Bilimler Fakültesi Dergisi, 31(1), 57-93. 
Bruck, C., Allen, T. D. \& Spector, P. E. (2002). The relation between work family conflict and job Satisfaction: A finer-grained analysis. Journal of Vocational Behavior, 60, 336-353.

Clark, S. C. (2000). Work-family border theory: A new theory of work/life balance. Human Relations, 53(6), 747-770.

Çelik, M., Turunç, Ö., ve Bilgin, N. (2014). Çalışanların Örgütsel Adalet Algılarının Psikolojik Sermaye Üzerindeki Etkisine Etkisi: Çalışanların İyilik Halinin Düzenleyici Rolü. Dokuz Eylül Üniversitesi Sosyal Bilimler Enstitüsü Dergisi, 16(4), 559-585.

Çetin, F. ve Basım, H. N. (2012). Örgütsel Psikolojik Sermaye: Bir Ölçek Uyarlama Çalışması, Amme İdaresi Dergisi, 45(1), 121-137.

Çoban, A. (2013). Psikolojik Sermayenin Örgütsel Adalet ve Örgütsel Bağlllık İlişkisi Üzerindeki Rolü. Organizasyon ve Yönetim Bilimleri Dergisi, 5(2), 17-33.

Delecta, P. (2011). Work life balance. International Journal of Current Research, III/4, 186-189.

Ekin, A. (2018). Beden Eğitimi ve Spor Öğretmenlerinde Pozitif Psikolojik Sermaye Algılarının Bazı Değişkenler Açısından İncelenmesi, Yüksek Lisans Tezi, Karamanoğlu Mehmetbey Üniversitesi SBE Beden Eğitimi ve Spor Ana Bilim Dalı.

Gül, H. (2003). Karizmatik Liderlik ve Örgütsel Bağl1lık İlişkisi Üzerine Bir Araştırma, Gebze Yüksek Teknoloji Enstitüsü Sosyal Bilimler Enstitüsü, Doktora Tezi, Gebze.

Hrebiniak, L. G. \& Alutto, J. A. (1972). Personal and role-related factors in the development of organizational commitment. Administrative Science Quarterly, 17, 555-572.

Karacan, T. M. (2018). Pozitif Psikolojik Sermaye ile Örgütsel Bağlılık İlişkisi İlbank Örneği, İller Bankası Anonim Şirketi., Uzmanlık Tezi, Ankara.

Kim, J. S., \& Ryu, S. (2017). Employee satisfaction with work-life balance policies and organizational commitment: A Philippine study. Public Administration and Development, 37(4), 260-276.

Korkmaz, O., \& Erdoğan, E. (2014). İş Yaşam Dengesinin Örgütsel Bağlllık ve Çalışan Memnuniyetine Etkisi. Ege Academic Review, 14(4), 541-557.

Koch, J. L. and Steers, R. M. (1978). Job attachment, satisfaction, and turnover among public employees. Journal of Vocational Behavior, 12, 119-128.

Küçükusta, D. (2007). Konaklama İşletmelerinde İş Yaşam Dengesinin Çalışma Yaşamı Kalitesine Etkisi, Doktora Tezi, Dokuz Eylül Üniversitesi Sosyal Bilimler Enstitüsü, İzmir.

Luthans, F., Avey, J. B., Avolio, B. J., Norman, S. \& Combs, G. M. (2006). Psychological capital development: Toward a micro-intervention. Journal of Organizational Behaviour, 27, 387-393. doi: 10.1002/job.373.

Luthans, F., Avolio, B., Avey, J., \& Norman, S. (2007a). Positive psychological capital: measurement and relationship with performance and satisfaction. Personnel Psychology, 60, 541-572. 
Luthans, F., Youssef, C. M., and Avolio, B. J. (2007b). Psychological Capital: Developing the Human Competitive Edge. New York: Oxford University Press.

Malone, E. K., \& Issa, R. R. (2013). Work-life balance and organizational commitment of women in the US construction industry. Journal of Professional Issues in Engineering Education and Practice, 139(2), 87-98.

Maslach, C. \& Jackson, S. E. (1981). The measurement of experienced burnout. Journal of Occupational Behavior, 2, 99-113.

Mathieu, J. E. \& Zajac, D. M. (1990). A Review and meta-analysis of the antecedents, correlates and consequences of organizational commitment. Psychological Bullettin, 108(2), 171-194.

Mercan, N., Demirci, K., Ergun Ozzler, D. ve Oyur, E. (2015). İs, Yaşamında Yalnızlık, Duygusal Zekâ ve Psikolojik Sermaye Arasındaki İlişkiler Üzerine Bir Araştırma, Manas Sosyal Araştırmalar Dergisi, 4(5), 197-211.

Meydan, C. H. ve Şeşen, H. (2015). Yapısal Eşitlik Modellemesi Amos Uygulamaları. Ankara: Seçkin Yayınevi.

Meyer, J. P., \& Allen, N. J. (1997). Commitment in the Workplace: Theory, Research, and Application. Sage.

Morris, J. H., \& Koch, J. L. (1979). Impacts of Role Perceptions on Organizational Commitment, Job Involvement, and Psychosomatic Illness among Three Vocational Groupings. Journal of Vocational Behavior, 14(1), 88-101.

Morrow, P. C. (1983). Concept redundacy in organizational research: The case of work commitment. Academy of Management Review, 8, 486-500.

Mowday, R. T. (1998). Reflections on the study and relevance of organizational commitment. Human Resource Management Review, 8(4), 387-401.

Mowday, R. T., Porter, L. W. \& Steers, R. M. (1982). Employee-Organization Linkages, New York, Academic Press, p.365.

Nguyen, T. D. \& Nguyen, T. T. M. (2011), Firm-Spesific Marketing Capital And Job Satisfaction Of Marketers: Evidence From Vietnam. The Learning Organization, 18(3), 251-263.

Ocak, M., Güler, M. ve Basım, H. N. (2016). Psikolojik Sermayenin Örgütsel Bağl1lık ve Is, Tatmini Tutumları Uzzerine Etkisi: Bosnalı Öğretmenler Üzerine Bir Araştırma. Çankırı Karatekin Üniversitesi İIBF Dergisi, 6(1), 113-130.

Özen Kutanis, R. ve Oruç, E. (2014). Pozitif Örgütsel Davranış, ve Pozitif Psikolojik Sermaye Üzerine Kavramsal Bir İnceleme. The Journal of Happiness $\mathcal{E}$ Well-Being, 2(2), 145-159.

Peterson, S. J., Luthans, F., Avolio, B. J., Walumbwa, F. O., \& Zhang, Z. (2011). Psychological capital and employee performance: A latent growth modeling approach. Personnel Psychology, 64, 427-450.

Pichler, F. (2009). Determinants of Work-life Balance: Shortcomings in the Contemporary Measurement of WLB in Large-Scale Surveys. Soc Indic Res, 92, 449-469. 
Porter, L. W., Steers, R. M., Mowday, R. T. \& Boulian, P. V. (1974). Organizational commitment, job satisfaction and turnover among psychiatric technicians. Journal of Applied Psychology, 59(5), 603-609.

Pradhan, R. K., Jena, L. K., \& Kumari, I. G. (2016). Effect of work-life balance on organizational citizenship behaviour: Role of organizational commitment. Global Business Review, 17(3_suppl), 15-29.

Quick, J., Nelson D. \& Hurrel, J. (1997). Preventive Stress Management in Organizations, American Psychological Association, Washington D.C.

Sayın, M. (2017). Serbest Muhasebeci Mali Müşavirlerin İş-Yaşam Dengesi Üzerine Bir Araştırma: Diyarbakır Örneği. Yüksek Lisans Tezi, Hasan Kalyoncu Üniversitesi Sosyal Bilimler Enstitüsü, Gaziantep.

Sen, C., \& Hooja, H. (2015). Psychological Capital \& Work-Life Balance: A Study on Police Officers. International Journal of Management and Social Sciences Research, 4, 7. 93-96.

Steers, R. M. (1977). Antecedents and outcomes of organizational commitment. Administrative Science Quarterly, 22, 45-46.

Tuncer, M. ve Yeşiltaş, M. (2013). Çalışma Yaşam Kalitesinin Otel İşletmesi Çalışanları Üzerindeki Etkileri. İşletme Araştırmaları Dergisi, 5(1), 57-78.

Uygungil, S. ve İşcan, Ö. F. (2018). Pozitif Psikolojik Sermaye, Örgütsel Bağl1lık ve Örgütsel Sinizm Arasındaki İlişkilerin İncelenmesi. Journal of Suleyman Demirel University Institute of Social Sciences, 31(1).

Vandenberg, R. J., \& Scarpello, V. (1994). A longitudinal assessment of the determinant relationship between employee commitments to the occupation and the organization. Journal of Organizational Behavior, 15(6), 535-547.

Yaşar, M. (2014). İstatistiğe Yönelik Tutum Ölçeği: Geçerlilik ve Güvenirlik Çalışması. Pamukkale Üniversitesi Ĕ̆itim Fakültesi Dergisi, 36(36), 59-75.

Yeşil, S., Yetiş, E. ve Telli, S. (2016). Psikolojik Sermaye ve C,alışanlar Üzerinde Etkisi: Banka Sektöründe Bir Alan Çalışması. International Journal of Academic Value Studies, 2(2), 2540 .

Yüksel, İ. (2004). Çalışma Yaşam Kalitesinin Tipik ve A Tipik İstihdam Açısından İncelenmesi. Doğuş Üniversitesi Dergisi, V(1), 47-58. 